\title{
Characteristics of wood pellets mixed with torrefied rice straw as a biomass fuel
}

\author{
Ryosuke Kizuka $^{1} \cdot$ Kazuei Ishii ${ }^{1}$ Masahiro Sato ${ }^{1} \cdot$ Atsushi Fujiyama $^{2}$
}

Received: 13 February 2019 / Accepted: 17 April 2019 / Published online: 27 April 2019

(c) The Author(s) 2019

\begin{abstract}
Utilization of rice straw as an alternative fuel source to fossil fuel has been considered. However, properties such as water content, low heating value, less grindability, high bulk density, and high ash content are problems in such a biomass fuel supply chain. This study attempted to produce wood pellets mixed with torrefied rice straw (WPTRS) to solve the problems related to using rice straw as fuel. For that, preferred torrefaction conditions, such as torrefaction temperature and holding time, were determined by indicators of the grindability, energy loss, and heating value. As a result, the preferred grindability was found at torrefaction temperatures of over $220^{\circ} \mathrm{C}$. In terms of energy, we derived two viewpoints: i.e., if minimum energy loss is prioritized, the preferred torrefaction temperature is $220^{\circ} \mathrm{C}$, and for an increase in the heating value of rice straw, $280{ }^{\circ} \mathrm{C}$ was preferred. Next, WPTRS was produced using rice straw torrefied at $220^{\circ} \mathrm{C}$ and $280{ }^{\circ} \mathrm{C}$, and by changing the mixing ratio of rice straw to wood. Burning tests were conducted to clarify the WPTRS characteristics and the results revealed that the torrefaction at a temperature of $280^{\circ} \mathrm{C}$ increased WPTRS's heating value. In addition, the basicity can be used as a good indicator for clinker production when wood and rice straw are used as fuel.
\end{abstract}

Keywords Agriculture biomass · Torrefaction · Wood pellets mixed with torrefied rice straw · Clinker production

\section{Introduction}

Renewable and sustainable energy is of global interest because fossil fuels have been exhausted and greenhouse gases are being emitted. The European Commission compiled a new policy framework for climate and energy for the period from 2020 to 2030, in which a target in the share of renewable energy consumption is at least $27 \%$, and in the electricity sector in particular, the share must be at least $45 \%$ [1]. In Japan, solar and wind power generation and electricity saving have been promoted by the feed-in tariff scheme. However, the share of biomass energy in electricity and heat is still low [2].

There is an abundance of agricultural residues, such as rice straw, rice husk and wheat straw in Japan, including

Kazuei Ishii

k-ishii@eng.hokudai.ac.jp

1 Faculty of Engineering, Hokkaido University, N13, W8, Kita-ku, Sapporo 060-8628, Japan

2 Institute of Environmental Science and Technologies, The University of Kitakyushu, 1-1, Hibikino, Wakamatsu-ku, Kitakyushu 808-0135, Japan in Hokkaido. However, most of the agricultural residue is returned into the soil as organic matter to enrich the soil [3], which means that the utilization ratio of agricultural residue, except for the straw return, is only $30 \%$ [4]. Though biomass fuel, such as rice straw, is an attractive energy source that can replace fossil fuel in terms of carbon neutrality, utilization of agricultural residues has many shortcomings, such as high moisture content, low bulk density, low heating value, high ash content, hygroscopic nature, low energy density, and poor grindability [5] [6]. For example, the low bulk density means that large spaces are required to store agricultural residues, and poor grindability and high moisture content need pretreatment processes, such as shredding and drying, before producing biomass fuel. High ash content also causes clinkers during a burning process.

During 2011, Nanporo was the first town in Hokkaido that started a business to use rice straw pellets. To mitigate the clinker problem, Nanporo introduced a co-combustion process of rice straw pellets and wood pellets in the ratio of 1:1 [7]. The above shortcomings of rice straw for utilization as biomass fuels can be overcome by applying torrefaction, although torrefaction requires energy. Our approach is to produce pellets using both wood and 
torrefied rice straw. Torrefaction of rice straw as pretreatment before pelletization, and production of wood pellets mixed with the torrefied rice straw (WPTRS) would contribute to the wider use of lignocellulosic biomass as fuel for local heat supply, which would benefit the regional economy.

The torrefaction process is a thermal treatment process in an inert atmosphere and in the low temperature range of $200-300{ }^{\circ} \mathrm{C}$ [8]. The torrefied product retains a maximum of $90 \%$ of its original energy content, while losing a maximum of $30 \%$ of its original mass, which is due to a partial loss of the volatile matter and moisture contained in the biomass [6]. It depolymerizes the long polysaccharide chains, producing a hydrophobic solid product with an increased energy density (on a mass basis). This process also partially decomposes the hemicellulose in the biomass fiber [9]. As a result, much less energy is required to grind the torrefied biomass $[10,8]$. Moreover, pelletizing is a process applying a mechanical force to compact biomass residues into uniformly sized solid particles. The objectives of pelletization are to increase the volumetric energy density [5]. Therefore, combining torrefaction and pelletization can solve the above shortcomings related to transport, handling, and storage [11].

According to Chen et al. [11], the number of studies on torrefaction of biomass has increased since 2008. They comprehensively reviewed torrefaction processes and properties of torrefied biomass, such as moisture content, volatile matter, fixed carbon and elemental contents, solid yield, energy density and energy yield, and grindability for various kinds of biomass (bagasse, bamboo, rice husk, sawdust, spruce, willow, and wheat straw). Prins et al. [12] studied the weight-loss kinetics for torrefaction of willow by isothermal thermogravimetry and analyzed the torrefied wood and the volatile product. The effect of process conditions, such as temperature and residence time on the yield and composition of solid product and volatile product, was studied. Ohliger et al. [13] conducted a parametric study of beechwood torrefaction with a continuously, indirectly heated reactor having a throughput of the order of $1 \mathrm{~kg}$ (product) $/ \mathrm{h}$, wherein each parameter was varied independently. Besides ultimate and proximate analyses of the products, grindability tests were performed and the heat of reaction was also determined. Keipi et al. [14] examined and compared the effect of torrefaction on the heating value, elementary composition, and chlorine content of eight woody biomasses. Chen et al. [15] investigated the release and transformation characteristics of $\mathrm{K}$ and $\mathrm{Cl}$ during straw torrefaction and mild pyrolysis under different conditions due to the variation of contents and chemical form. Moreover, Chen et al. [16] investigated the influence of torrefaction on the physicochemical characteristics of char during raw and water washed rice straw pyrolysis and compared pore structure, aromaticity, and gasification activity of pyrolysis chars between raw and torrefied samples.

In terms of pelletization, Stelte et al. [17] analyzed the torrefaction and pelletizing properties of wheat straw. In their study, infrared spectroscopy and chemical analyses showed that the high torrefaction temperatures changed the chemical properties of the wheat straw significantly and pelletizing analyses showed that these changes in chemical properties correlate with the changes in the pelletizing properties. Torrefaction increased the friction in the press channel, while pellet strength and density decreased with an increase in torrefaction temperature. Regarding usage of pellets using torrefied agricultural residues, no studies were found related to the use of them, especially in small and/or middle scale of biomass boilers in public facilities or greenhouses and biomass stoves in houses.

From our review of studies on torrefaction and pelletization of agriculture residue, it appears that no studies on pelletization of both wood and torrefied rice straw have been done. Fundamental data on torrefaction conditions (temperature and holding time) for rice straw to produce WPTRS should be obtained and combustion properties (ash and clinker generation) for WPTRS should be clarified. Therefore, this study focused on WPTRS to improve the problems related to the supply chain for biomass fuels using rice straw. In particular, the effectiveness of torrefaction of rice straw on the quality of WPTRS was analyzed from an energy balance perspective. WPTRS were produced and experimentally burned to determine the combustion characteristics of WPTRS regarding its clinker problems.

\section{Materials and method}

\section{Rice straw}

The rice straw used in this study was collected in November 2014 from the town of Nanporo in Hokkaido, Japan. The collected rice straw was stored at room temperature, in the order of $20-25{ }^{\circ} \mathrm{C}$, in the laboratory of Hokkaido University. Our experiments were conducted in the winter of 2016. The moisture content was $6.5 \%$, and the ash content was $18.0 \%$.

\section{Torrefaction method}

The rice straw was torrefied in a stainless-steel reactor placed in an electric drying oven. The plan and side views of the reactor are shown in Fig. 1. The raw rice straw was put in the reactor, which was sealed and placed into the electric drying oven. The reactor was heated to the designated temperature $\left(190-280^{\circ} \mathrm{C}\right)$ under a non-oxygen environment made up by flowing nitrogen gas. The temperature inside the reactor was increased by $1{ }^{\circ} \mathrm{C} / \mathrm{min}$ up 

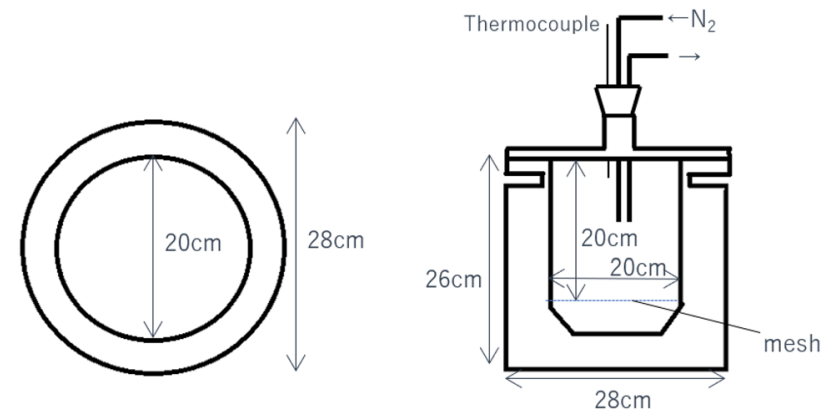

Plan view (with the lid off)

Side view

Fig. 1 Plan and side views of the reactor

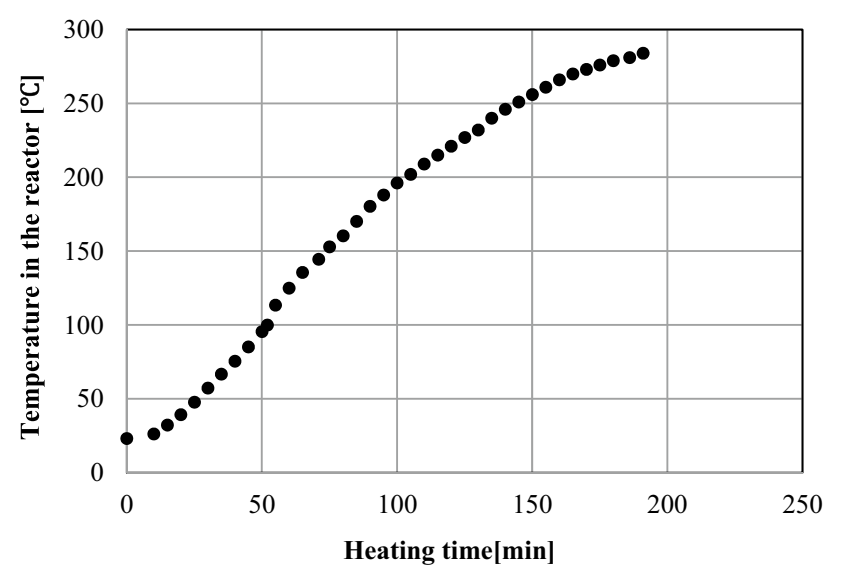

Fig. 2 Change in the reactor's internal temperature (the torrefaction temperature was $280^{\circ} \mathrm{C}$ )

to $40{ }^{\circ} \mathrm{C}$, and by $2{ }^{\circ} \mathrm{C} / \mathrm{min}$ up to $200{ }^{\circ} \mathrm{C}$ (Fig. 2). As the temperature increased further, the temperature rises gradually became slower. After the temperature reached the designated temperature (i.e., the torrefaction temperature), the temperature was maintained for a designated holding time (0-120 $\mathrm{min})$. The reactor was then cooled down naturally to room temperature. The torrefied rice straw was weighed and shredded with a continuous mill (IKA MF10 basic, Germany). The shredded rice straw was discharged through a $3-\mathrm{mm}$ mesh. The torrefaction conditions, such as
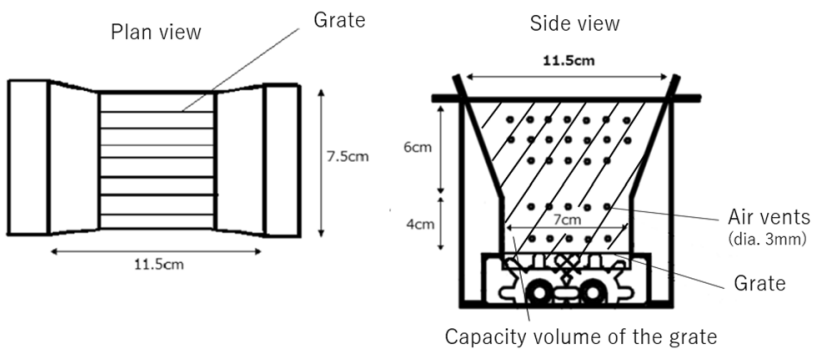

Fig. 3 Shape and dimensions of the grate in the pellet stove

the torrefaction temperature and holding time, are shown in Table 1.

\section{Production of WPTRS}

The rice straw was torrefied with the same reactor, and shredded using a 1-mm mesh mill. A pelletizer (EF-BS055; Earth Engineering Co., Ltd., Japan; capacity: $20 \mathrm{~kg} / \mathrm{h}$, diameter of die: $6 \mathrm{~mm}$, forming temperature: $60{ }^{\circ} \mathrm{C}$ ) was used at the Hokkaido Research Organization, Forest Products Research Institute. Wood was provided from the wood-processing industry that produces wood pellets. Moisture content, ash content, and lower heating value of the wood were $6.6 \%, 1.18 \%$, and $16.3 \mathrm{MJ} / \mathrm{kg}$, respectively.

The dried or torrefied rice straw, and the wood were mixed at the designated ratio in weight. Water was added so that the moisture content was approximately $15 \%$ and it was thoroughly stirred by hand. The mixture was put into a flat die molding machine to form pellets of rice straw and wood with a diameter of $6 \mathrm{~mm}$ and a length of approximately $3 \mathrm{~cm}$.

\section{Ash formation test}

A pellet stove (FFP701-DF-1, Sunpot Corporation, Japan) was used. The shape and dimensions of the grate in the pellet stove are shown in Fig. 3. The ignition method uses electricity, and the maximum capacity for heating is $7797 \mathrm{kcal} / \mathrm{h}$ when wood pellets are used. The pellets were supplied into the grate from above and burned by the inflowing air from the bottom of the grate. The small particle ash fell from the

Table 1 Torrefaction conditions

\begin{tabular}{llllllll}
\hline & \multicolumn{7}{l}{ Holding time (min) } \\
\cline { 3 - 7 } \cline { 3 - 7 } & & 0 & 10 & 30 & 60 & 90 & 120 \\
\hline Torrefaction temperature $\left({ }^{\circ} \mathrm{C}\right)$ & 190 & $\checkmark$ & & $\checkmark$ & & \\
& 220 & $\checkmark$ & & & $\checkmark$ & & $\checkmark$ \\
& 250 & $\checkmark$ & & & $\checkmark$ & & $\checkmark$ \\
& 280 & & $\checkmark$ & $\checkmark$ & $\checkmark$ & $\checkmark$ & \\
\hline
\end{tabular}


bottom of the grate to the ash tray. The pellet stove has a detector for ash accumulation, and when a certain volume of ash accumulates on the grate, the detector stops the pellet supply automatically in $30 \mathrm{~min}$. For periodical maintenance of the grate, there is an ash treatment device with crusher for the ash at the bottom of the grate. It can be worked only manually for cleaning, but it was not used during this ash formation test. The spacing of the partitions on the grate is $5 \mathrm{~mm}$. The capacity volume of the grate is $626 \mathrm{~cm}^{3}$ (Fig. 3).

Wood pellets and wood pellets mixed with dried or torrefied rice straw were burned for ash formation tests. After completion of the tests, the ash was sampled, categorized into two kinds of ashes, i.e., ash on the grate and the other ash, and weighed. The ash on the grate refers to the ash accumulated on the grate, while the other ash refers to the ash passing through the grate and the fly ash falling on the ash tray. However, there is one more type of fly ash, which is discharged out of the stove through the chimney pipe. Since this type of fly ash cannot be weighed, the fly ash discharged to the outside was estimated by subtracting the amount of ash on the grate and the other ash from the total amount of ash supplied into the pellet stove based on the ash content of pellets.

\section{Analysis method}

\section{Higher heating value (HHV)}

In accordance with the Japanese Industrial Standards M 8814 [18], the higher heating values (HHV) of the samples were measured using a bomb calorimeter (C7000, IKA, Germany). One mass of approximately $0.5 \mathrm{~g}$ of shredded samples was analyzed and it was repeated four times.

\section{Hydrogen content and lower heating value (LHV)}

Hydrogen content was measured using an elemental analyzer (Elementar Vario EL; Elementar Analyzer System, Germany). Each run was repeated four times. The lower heating values (LHV) were calculated from their HHV and hydrogen content using Eq. (1):

$\mathrm{LHV}=\mathrm{HHV}-r \times(U+9 \mathrm{H})$,

where LHV and HHV are the lower and higher heating values $(\mathrm{MJ} / \mathrm{kg})$, respectively, $r$ is the evaporative latent heat $(2500 \mathrm{~kJ} / \mathrm{kg}), U$ is the moisture content $(\mathrm{kg} / \mathrm{kg})$ and $\mathrm{H}$ is the hydrogen content $(\mathrm{kg} / \mathrm{kg})$.

\section{Remaining heating value rate}

Torrefaction increases the heating value per weight of rice straw. However, some energy is lost because volatile matter is thermally decomposed. To evaluate the energy loss during torrefaction, the remaining heating value rate (RHVR) was calculated from Eq. (2). This indicator is also called the energy yield [11]:

RHVR

$$
=\frac{L H V \text { for torrefied rice straw } \times \text { weight of torrefied rice straw }}{L H V \text { for dried rice straw } \times \text { weight of dried rice straw }} .
$$

\section{Thermogravimetric analysis (TG) and differential thermal} analysis (DTA)

Dried and shredded rice straw was heated to $300{ }^{\circ} \mathrm{C}$ with a simultaneous thermogravimetric analyzer (STA7300; Hitachi, Japan), and the thermal weight and differential heat were measured twice. The heating program was then set as follows, based on the temperature rise in this experiment and as described in Sect. 2.2:

1. From room temperature to $40{ }^{\circ} \mathrm{C}$ at $1{ }^{\circ} \mathrm{C} / \mathrm{min}$

2. From 40 to $200^{\circ} \mathrm{C}$ at $2{ }^{\circ} \mathrm{C} / \mathrm{min}$

3. From 200 to $260^{\circ} \mathrm{C}$ at $1{ }^{\circ} \mathrm{C} / \mathrm{min}$

4. From 260 to $280{ }^{\circ} \mathrm{C}$ at $0.5^{\circ} \mathrm{C} / \mathrm{min}$

5. From 280 to $300{ }^{\circ} \mathrm{C}$ at $0.2^{\circ} \mathrm{C} / \mathrm{min}$

\section{Particle size distribution}

Particle size distribution was measured to evaluate the grindability of torrefied rice straw, using seven types of test sieves, whose mesh sizes were $0.075,0.125,0.25,0.5,1.0,2.0$ and $5.6 \mathrm{~mm}$.

\section{Strength of ash on the grate}

For the ash on the grate, the maximum value of the strength until the ash was completely collapsed was measured using a digital force gauge (ZTA-200 N, Imada, Japan).

\section{Component and basicity of ash on the grate}

T component of the ash on the grate was measured using a fluorescent X-ray element analyzer (MESA-500; Horiba, Japan). In addition, the basicity was calculated with Eq. (3), using the content of the components of the ash on the grate. Basicity is one of the indicators showing the ash state in the field of coal combustion. The tendency of hard ashes generation, which is called clinker, is high when the basicity is 0.4 or more [19]:

Basicity $[-]=\frac{\mathrm{Fe}_{2} \mathrm{O}_{3}+\mathrm{CaO}+\mathrm{MgO}+\mathrm{Na}_{2} \mathrm{O}+\mathrm{K}_{2} \mathrm{O}}{\mathrm{SiO}_{2}+\mathrm{Al}_{2} \mathrm{O}_{3}+\mathrm{TiO}_{2}}$. 


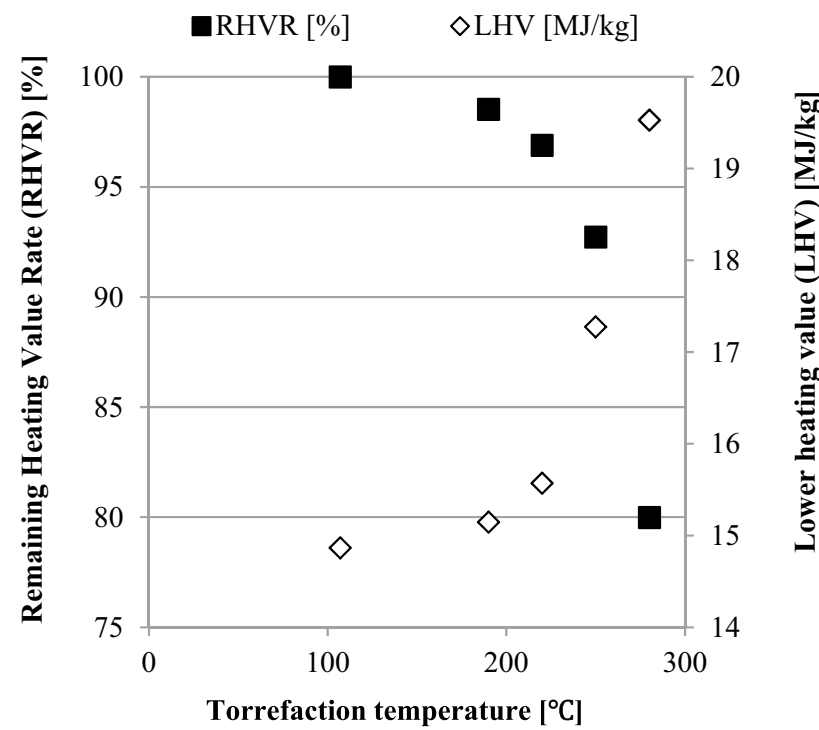

Fig. 4 Relationships of LHV and RHVR vs torrefaction temperature

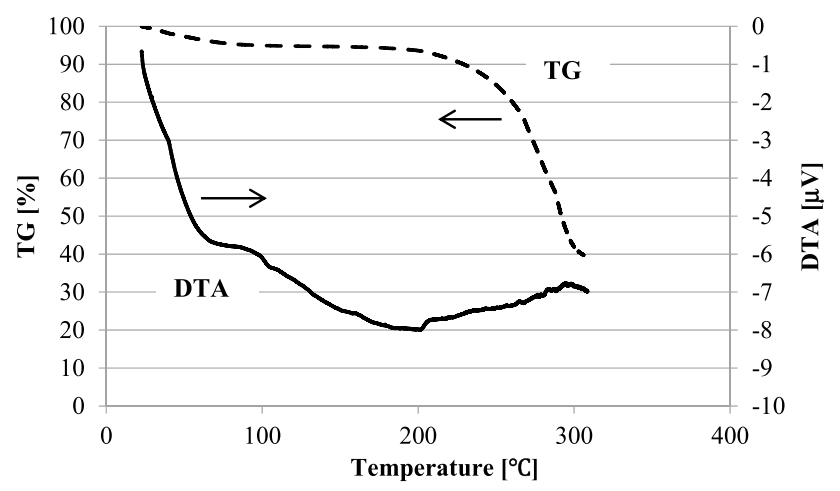

Fig. 5 Results of TG-DTA of rice straw

\section{Results and discussion}

\section{Heating value and remaining heat value rate}

The relationships among the torrefaction temperature, LHV, and RHVR are shown in Fig. 4. The LHV of torrefied rice straw increased with the torrefaction temperature because the reduction in weight of the rice straw accompanied by torrefaction was larger than the decrease in the volatile content of the rice straw. Figure 5 shows the results of the TG-DTA for the dried rice straw under the same condition of temperature increase rate in this experiment, although the final temperature was set to $300{ }^{\circ} \mathrm{C}$. Hemicellulose and cellulose in the rice straw appeared to be mainly decomposed. The decomposition temperatures for hemicellulose and cellulose are $200-260^{\circ} \mathrm{C}$ and $240-350{ }^{\circ} \mathrm{C}$
[20], respectively. The TG and DTA decreased, so the drying process was seen up to $100{ }^{\circ} \mathrm{C}$ because of a water content increase during storage (Fig. 5). Until $200{ }^{\circ} \mathrm{C}$, the DTA further decreased because of removal of bound water. Reduction in the weight of the rice straw started and radiation of the heat (see DTA) started when the temperature exceeded $200{ }^{\circ} \mathrm{C}$, which means that decomposition of hemicellulose started. When the temperature exceeded $250{ }^{\circ} \mathrm{C}$, the weight was further reduced significantly and the radiation of heat continued. Cellulose was decomposed during this temperature range around $250{ }^{\circ} \mathrm{C}$. At the temperature of $300{ }^{\circ} \mathrm{C}$, the decomposition seemed to end. The increase in the LHV of torrefied rice straw (Fig. 4) had the same tendency as the result of the TG-DTA. The LHV of rice straw at the torrefaction temperature of $280{ }^{\circ} \mathrm{C}$ was over $19 \mathrm{MJ} / \mathrm{kg}$, which was higher than for wood pellets with an LHV of $16.9 \mathrm{MJ} / \mathrm{kg}$ [21]. Therefore, torrefaction contributes to an increase in the LHV of rice straw.

Although torrefaction increased the heating value per unit weight of rice straw, a part of the energy in the dried rice straw was lost. In addition, the ash content increased relatively due to the reduction of volatile matter. To evaluate torrefaction from the viewpoint of energy loss, the RHVR is also shown in Fig. 4. The definition of RHVR, as shown in Eq. (2), means that the RHVR is 1.0 when the torrefaction temperature is $100{ }^{\circ} \mathrm{C}$ (just drying). The RHVR decreased with an increase in the torrefaction temperature because the volatile matter was reduced with an increase in the torrefaction temperature. For torrefaction temperatures less than $220{ }^{\circ} \mathrm{C}$, the RHVR was still over $95 \%$. However, the RHVR was significantly decreased at torrefaction temperatures of more than $0{ }^{\circ} \mathrm{C}$. When the torrefaction temperature was $280{ }^{\circ} \mathrm{C}$, the RHVR was $80 \%$. This means that $20 \%$ of energy in the dried rice straw was lost through torrefaction, although the LHV of torrefied rice straw was improved.

\section{Grindability}

The torrefied rice straw was broken easily with one's fingers, especially when the torrefaction temperature was $220^{\circ} \mathrm{C}$, $250{ }^{\circ} \mathrm{C}$, and $280^{\circ} \mathrm{C}$. This was because a part of the hemicellulose and cellulose was decomposed. However, the rice straw torrefied at $190{ }^{\circ} \mathrm{C}$ could not be broken easily with one's fingers.

The comparison of particle size distribution for shredded torrefied rice straw is shown in Fig. 6, where the plots are denoted as $X{ }^{\circ} \mathrm{C}-Y$ min; $X$ indicates the torrefied temperature, and $Y$ indicates the holding time. The particle size of the rice straw torrefied at $190{ }^{\circ} \mathrm{C}, 220{ }^{\circ} \mathrm{C}$, and $250{ }^{\circ} \mathrm{C}$ was smaller than that of the dried rice straw. In particular, and regardless of the holding time, there was no significant difference in particle size for rice straw torrefied at $220^{\circ} \mathrm{C}$ and $250{ }^{\circ} \mathrm{C}$. Therefore, torrefaction at the temperature of over 
Fig. 6 Comparison of particle size distribution for shredded rice straw

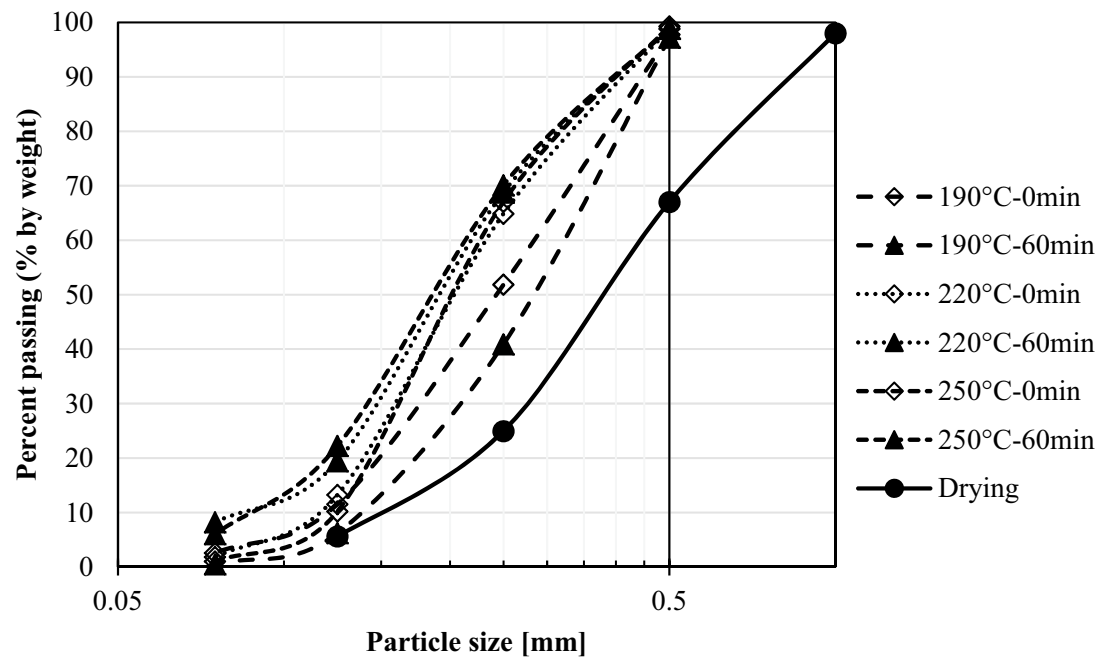

$220^{\circ} \mathrm{C}$ seemed to be enough to improve the grindability of rice straw. Arias et al. [22] studied the changes in the grindability characteristics of biomass samples (eucalyptus) when subjected to mild pyrolysis treatment (torrefaction) in the temperature range of $240-280{ }^{\circ} \mathrm{C}$.

The difference in the particle size distribution of shredded rice straw for holding times between 0 and 60 min was small, although the difference at the torrefaction temperature of $190{ }^{\circ} \mathrm{C}$ was a little bit larger than those at the other temperatures of $220^{\circ} \mathrm{C}$ and $250^{\circ} \mathrm{C}$. In general, there is a significant mass loss initially, which is associated with the decomposition of some reactive components of the hemicellulose. At higher holding times, the mass loss can be attributed to the decomposition of the less reactive components of the hemicellulose. In this study, because a very slow heating rate was used $\left(1-2{ }^{\circ} \mathrm{C} / \mathrm{min}\right)$, it seemed that reaction had progressed to a certain extent when the temperature reached the designated torrefaction temperature. That is why, there was no significant difference in the particle size distribution between 0 and $60 \mathrm{~min}$ in the holding time.

\section{Preferred torrefaction conditions from the viewpoint of energy and grindability}

As the torrefaction temperature increased, the heating value per weight unit of rice straw increases. However, energy loss occurred in terms of the total energy in the rice straw, as mentioned above. Therefore, the preferred torrefaction conditions can be discussed as follows, considering both the energy loss and grindability.

\section{Minimization of energy loss}

The energy required for torrefaction and the energy loss during the torrefaction process should be minimized. From our data on torrefaction of rice straw, the preferred torrefaction temperature is $220{ }^{\circ} \mathrm{C}$, because the RHVR was over $95 \%$ and the grindability was also improved. Torrefaction temperatures of 250 and $280{ }^{\circ} \mathrm{C}$ are not needed because the energy loss is large. It is noted that the holding time should be further investigated because a very slow heating rate was used in this study. Further investigations are needed for faster heating rates.

\section{Improvement of quality of rice straw as fuel}

The other viewpoint is to produce biomass fuels with high quality that can be sold at a high price. Considering that the price of biomass energy can be determined by LHV, the preferred torrefaction temperature is $280{ }^{\circ} \mathrm{C}$. Longer holding times may increase the heating value, but may decrease the RHVR. Therefore, further investigation into the effects of holding time is needed.
Table 2 Feedstock condition and production amount of pellets

\begin{tabular}{lllll}
\hline & $\begin{array}{l}\text { Feedstock weight (Except for } \\
\text { addition of water) }\end{array}$ & $\begin{array}{l}\text { The mixing ratio of rice straw to } \\
\text { the produced pellets }\end{array}$ \\
\cline { 3 - 5 } \cline { 3 - 5 } & & $10 \%$ & $30 \%$ & $50 \%$ \\
\hline Method of treatment (Temperature) & Drying $\left(107{ }^{\circ} \mathrm{C}\right)$ & $7 \mathrm{~kg}$ & - & - \\
& Torrefaction $\left(220^{\circ} \mathrm{C}\right)$ & $7 \mathrm{~kg}$ & $5 \mathrm{~kg}$ & $2.8 \mathrm{~kg}$ \\
& Torrefaction $\left(280^{\circ} \mathrm{C}\right)$ & $7 \mathrm{~kg}$ & - & - \\
\hline
\end{tabular}


Table 3 Properties of wood pellets mixed with dried or torrefied rice straw

\begin{tabular}{lcllccc}
\hline Feedstock & Wood & \multicolumn{2}{l}{ Wood and rice straw } \\
\cline { 3 - 7 } Torrefaction temperature $\left({ }^{\circ} \mathrm{C}\right)$ & & 100 (Drying) & 220 & 220 & 220 & 280 \\
Mixing ratio of rice straw to wood $(\%)$ & & 10 & 10 & 30 & 50 & 10 \\
\hline LHV (MJ/kg) & 16.3 & 16.2 & 16.2 & 15.9 & 15.6 & 16.5 \\
Moisture content $(\%)$ & 6.94 & 5.85 & 6.25 & 6.50 & 9.37 & 9.79 \\
Ash content $(\%)$ & 1.18 & 1.65 & 2.54 & 2.47 & 4.97 & 6.53 \\
\hline
\end{tabular}

\section{Characteristics of WPTRS}

Based on the two viewpoints for the preferred torrefaction conditions on the torrefaction temperature, wood pellets were produced by mixing dried or torrefied rice straw. The mixing ratios of rice straw to wood were 10,30 , and $50 \%$ (Table 2). Torrefaction conditions included temperature of 220 and $280{ }^{\circ} \mathrm{C}$ and no holding time. In addition, dried rice straw was used as a reference. We did not consider all combinations of the mixing ratio and the torrefaction temperature because the high ash content of torrefied rice straw (the high mixing ratio) might cause a bad effect on continuous burning in the pellet stove, as described in later. Finally, 5 kinds of WPTRS were produced. For example, in the mixing ratio of rice straw to the produced pellets of $10 \%$, the amount of pellets produced is $7 \mathrm{~kg}$, using $6.3 \mathrm{~kg}$ wood and $0.7 \mathrm{~kg}$ rice straw torrefied at a temperature of $220^{\circ} \mathrm{C}$.

The LHV of dried rice straw was less than $15 \mathrm{MJ} / \mathrm{kg}$ (Fig. 4). The LHV of wood was $16.3 \mathrm{MJ} / \mathrm{kg}$ as described in Sect. 2.3. This explains why mixing rice straw with wood decreases the LHV of pellets, as the mixing ratio of rice straw to wood increases. In case of WPTRS (Table 3), when the torrefaction temperature was $220^{\circ} \mathrm{C}$, the LHV of WPTRS decreased as the mixing ratio of torrefied rice straw to wood increased. However, the LHV increased when the torrefaction temperature was $280{ }^{\circ} \mathrm{C}$ because the torrefaction at this temperature increased the LHV of rice straw significantly. Although it depends on the LHV of wood generally, this study found that torrefaction can improve heating values by mixing the wood with rice straw.

Table 3 also shows the moisture and ash content of wood pellets, wood pellets mixed with dried rice straw, and WPTRS. The moisture content varied from 6 to $9 \%$. Since water was added to reach a moisture content of approximately $15 \%$ before pelletization, it means that the moisture content was reduced by $6-9 \%$ during pelletization. The ash content was increased as the mixture ratio of rice straw and the torrefaction temperature increased, because the ash content increased by volatilization.

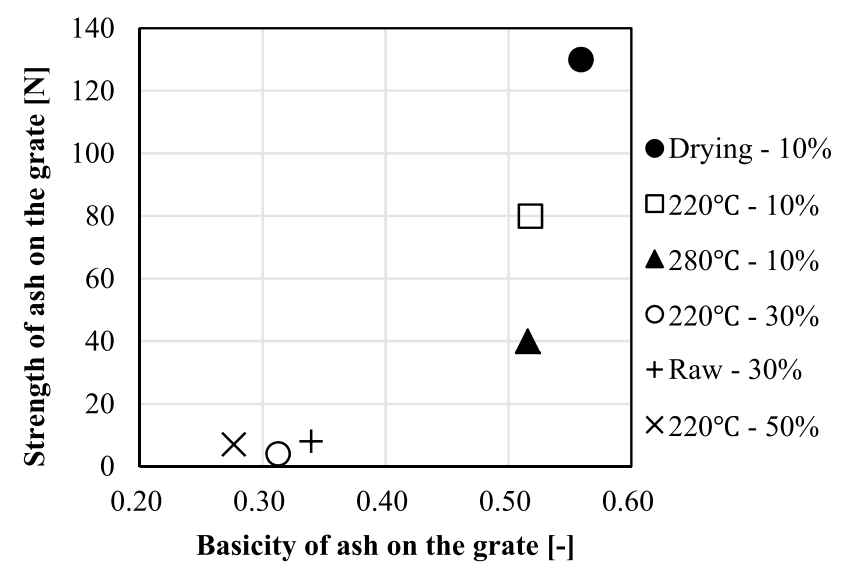

Fig. 7 Relationship between the strength and the basicity of ash on the grate

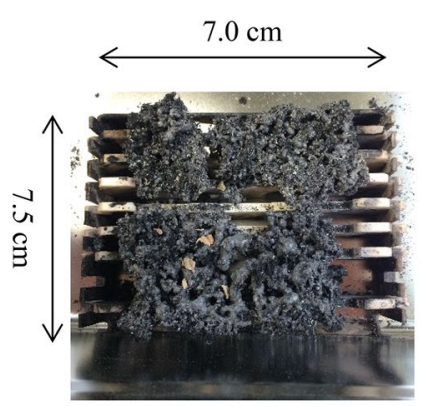

A $220^{\circ} \mathrm{C}, 10 \%(80 \mathrm{~N})$

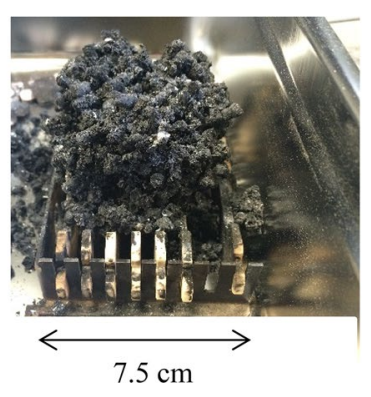

B $220^{\circ} \mathrm{C}, 30 \%$
Fig. 8 Pictures of ash on the grate

\section{Ash formation test}

As described before, the ash contents of rice straw and wood were $18.0 \%$ and $1.18 \%$, respectively. In the cases where the mixing ratios of rice straw to wood was $30 \%$ rice straw and $50 \%$ rice straw, it was impossible to continue to burn the pellets for $1 \mathrm{~h}$ because the total amount of ash was more than the other conditions with mixing ratios of $10 \%$ rice straw and $0 \%$ rice straw (wood only), and the accumulation volume of ash on the grate was much more significant than for the other conditions. 


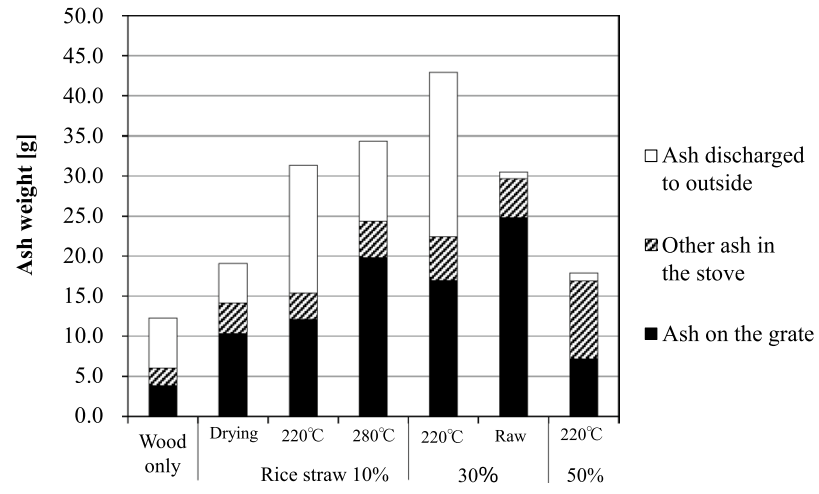

Fig. 9 Amount of ash generated during combustion of pellets

Figure 7 shows a relationship between the strength and the basicity of ash on the grate, where the plots were denoted as $\mathrm{X}{ }^{\circ} \mathrm{C}-\mathrm{Y} \%$; $X$ indicates the torrefaction temperature of rice straw and $Y$ indicates the mixture ratio of rice straw to wood in weight. It was revealed that the strength of ash on the grate with the basicity of less than 0.4 was as low as $10 \mathrm{~N}$ or less, and that the strength of ash on the grate with higher basicity generated strong clinker. Examples of pictures of the ash on the grate are shown in Fig. 8a, b. The ash with the strength value of less than $10 \mathrm{~N}$ (Fig. 8b) had a low density and was soft enough to be broken easily by one's fingers. The ash with strength values of more than $10 \mathrm{~N}$ (Fig. 8a) had higher densities and formed hard clinker. Therefore, the basicity can be used for the judgement of clinker production in cases of co-combustion of wood and rice straw.

Figure 9 shows the amount of ash generated during the combustion of pellets, indicating that the wood pellets mixed with raw rice straw discharged little ash to the outside. The raw rice straw was not dried before pelletization, but was only shredded into particle sizes of $15 \mathrm{~mm}$. On the other hand, wood pellets mixed with $10 \%$ of dried and torrefied rice straw, which was shredded to particle sizes of less than $1 \mathrm{~mm}$, increased the rate of ash discharged to the outside, and the amount of ash on the grate decreased. That is why the amount of fly ash discharged to the outside was lower when raw rice straw was used.

This fact indicated that the smaller particle size of rice straw increased the amount of ash discharged to the outside, resulting in the need for dust treatment. In addition, the rates of ash discharged to the outside using rice straw torrefied at temperatures of $220^{\circ} \mathrm{C}$ and $280{ }^{\circ} \mathrm{C}$ were larger than that using dried rice straw, except where the mixing ratio was $50 \%$ rice straw torrefied at a temperature of $220{ }^{\circ} \mathrm{C}$. As described above, continuous burning for $1 \mathrm{~h}$ was not possible in the case of the $50 \%$ mixing ratio because of the high accumulation of ash on the grate (In Fig. 9, the weight of ash on the grate in the case of the 50\% mixing ratio was smaller than those in the other cases at the same temperature of $220^{\circ} \mathrm{C}$, but in actual, the volume of ash was high and the period of continuous burning was short as described before). Further investigation is needed to clarify the relationships between the torrefaction temperature, particle size, mixing ratio to evaluate clinker production, accumulation of volume, and ash generation discharged to the outside.

\section{Conclusions}

The following conclusions were drawn from this experimental study.

1. The grindability of rice straw was improved by torrefaction at temperatures of over $220^{\circ} \mathrm{C}$. This study suggested two important viewpoints for torrefaction conditions of rice straw. One viewpoint is minimization of energy loss, where a torrefaction temperature of $220^{\circ} \mathrm{C}$ and no holding time was preferred. The other viewpoint is improvement of the quality of rice straw as a fuel, where a torrefaction temperature of $280{ }^{\circ} \mathrm{C}$ and no holding time was preferred.

2. Since the LHV of rice straw is lower than that of wood, the LHV of wood pellets mixed with rice straw is lower than that of wood alone. However, using the rice straw torrefied at a temperature of $280{ }^{\circ} \mathrm{C}$, the LHV of WPTRS was larger than that of wood at a mixing ratio of $10 \%$ rice straw, which means that torrefaction can improve the LHV of the wood pellets by mixing the wood with rice straw.

3. The basicity can be a good indicator to determine whether clinker will be produced by wood pellets mixed with rice straw.

Acknowledgements We thank the town of Nanporo, Koukyou-sizai Co., Ltd. and Hokkaido Forest Products Research Institute to for their assistance in preparing samples and producing pellets.

Open Access This article is distributed under the terms of the Creative Commons Attribution 4.0 International License (http://creativeco mmons.org/licenses/by/4.0/), which permits unrestricted use, distribution, and reproduction in any medium, provided you give appropriate credit to the original author(s) and the source, provide a link to the Creative Commons license, and indicate if changes were made.

\section{References}

1. Communication from the Comissio to the European Parliament, the Council, the European Economic and Social Committee of the Regions, A policy framework for climate and energy in the period from 2020 to 2030, EUR-Lex - 52014DC0015 - EN (2014). https ://eur-lex.europa.eu/legal-content/EN/ALL/?uri=CELEX:52014 DC0015. Accessed 26 April 2019 
2. (2016) IEA: energy policies of IEA countries -Japan 2016 review. https://www.iea.org/publications/freepublications/publi cation/EnergyPoliciesofIEACountriesJapan2016.pdf. Accessed 26 April 2019

3. Yagi, K., Minami, K.: Effect of organic matter application on methane emission from some Japanese paddy fields. Soil Sci Plant Nutr 36, 599-610 (1990)

4. Ministry of Agriculture, Forestry and Fisheries: Fundamental plan for promotion of biomass utilization (2016) http://www.maff. go.jp/j/shokusan/biomass/attach/pdf/index-4.pdf. Accessed date 3 Sept 2018 (In Japanese)

5. Werther, J., Saenger, M., Hartge, E.-U., Ogada, T., Siagi, Z.: Combustion of agricultural residues. Prog Energy Combust Sci 26, $1-27$ (2000)

6. Acharya, B., Dutta, A., Minaret, J.: Review on comparative study of dry and wet torrefaction. Sustain Energy Technol Assess 12, 26-37 (2015)

7. Ishii, K., Furuichi, T.: Influence of moisture content, particle size and forming temperature on productivity and quality of rice straw pellets. Waste Manag 34, 2621-2626 (2014)

8. van der Stelt, M.J.C., Gerhauser, H., Kiel, J.H.A., Ptasinski, K.J.: Biomass upgrading by torrefaction for the production of biofuels: a review. Biomass Bioenergy 35, 3748-3762 (2011)

9. Koppejan, J., Sokhansanj, S., Melin S., and Madrali S.: IEA Bioenergy Task 32 report. Final report, status overview of torrefaction technologies (2012). http://www.ieabcc.nl/publications/ IEA_Bioenergy_T32_Torrefaction_review.pdf. Accessed 3 Sept 2018

10. Bridgeman, T.G., Jones, J.M., Shield, I., Williams, P.T.: Torrefaction of reed canary grass, wheat straw and willow to enhance solid fuel qualities and combustion properties. Fuel 87, 844-856 (2008)

11. Chen, W.-H., Peng, J., Bi, X.T.: A state-of-the-art review of biomass torrefaction, densification and applications. Renew Sustain Energy Rev 44, 847-866 (2015)

12. Prins, M.J., Ptasinski, K.J., Janssen, F.J.J.G.: Torrefaction of wood part 1. Weight loss kinetics. J Anal Appl Pyrolysis 77, 28-34 (2006)
13. Ohliger, A., Förster, M., Kneer, R.: Torrefaction of beechwood: a parametric study including heat and grindability. Fuel 104, 607-613 (2013)

14. Keipi, T., Tolvanen, H., Kokko, L., Raiko, R.: The effect of torrefaction on the chlorine content and heating value of eight woody biomass samples. Biomass Bioenergy 66, 232-239 (2014)

15. Chen, H., Chen, X., Qiao, Z., Liu, H.: Release and transformation characteristics of $\mathrm{K}$ and $\mathrm{Cl}$ during straw torrefaction and mild pyrolysis. Fuel 167, 31-39 (2016)

16. Chen, H., Chen, X., Qin, Y., Wei, J., Liu, H.: Effect of torrefaction on the properties of rice straw high temperature pyrolysis char: pore structure, aromaticity and gasification activity. Bioresour Technol 228, 241-249 (2017)

17. Stelte, W., Nielsen, N.P.K., Hansen, H.O., Dahl, J., Shang, L., Sanadi, A.R.: Pelletizing properties of torrefied wheat straw. Biomass Bioenergy 49, 214-221 (2013)

18. (1993) Japanese Industrial Standards: coal and coke-determination of gross calorific value by the bomb calorimetric method, and calculation of net calorific value, JIS M 8814

19. CoalTech: Common slagging and fouling indices. http://www. coaltech.com.au/LinkedDocuments/Slagging\%20\&\%20Fouling. pdf. Accessed 3 Sept 2018

20. Mohan, D., Pittman, C.U., Steele, P.H.: Pyrolysis of wood/biomass for bio-oil: a critical review. Energy Fuels 20, 848-889 (2006)

21. García-Maraver, A., Popov, V., Zamoranoa, M.: A review of European standards for pellet quality. Renew Energy 36, 3537-3540 (2011)

22. Arias, B., Pevida, C., Fermoso, J., Plaza, M.G., Rubiera, F., Pis, J.J.: Influence of torrefaction on the grindability and reactivity of woody biomass. Fuel Process Technol 89, 169-175 (2008)

Publisher's Note Springer Nature remains neutral with regard to jurisdictional claims in published maps and institutional affiliations. 